\title{
Implementation of GCG (Good Corporate Governance) on the Prevention of Fraud Financing in Islamic Banks
}

\author{
${\text { Lies } \text { Cholisoh }^{1 *}, \text { M. Fuad Hadziq }}^{2}$ \\ ${ }^{1}$ Jurusan Perbankan Syariah, Fakultas Agama Islam, Universitas Islam Muhammadiya Jakarta, Indonesia \\ ${ }^{2}$ Program Studi Ekonomi Syariah, Fakultas Ekonomi, Universitas Terbuka, Indonesia \\ * Corresponding author e-mail: liescholisoh@yahoo.com
}

\begin{tabular}{l}
\hline Article Info \\
\hline Keywords: \\
Good Corporate Governance; \\
Islamic Banking; \\
Fraud. \\
\hline
\end{tabular}

DOI:

10.33830/elqish.v1i2.1569.2021

\begin{abstract}
Although Islamic Banking operates with Islamic principles, there are still many frauds that are committed deliberately for particular cases. This study aims to determine the extent of the influence of Good Corporate Governance in Islamic banking on indications of fraud, especially at Bank BNI Syariah. This research is quantitative research with primary and secondary data, namely using a sample questionnaire and interviews. While the data analysis is using multiple regression with descriptive analysis. The results of the study concluded that the resulting regression had a very small $R$ square at $34.7 \%$. Finding. The results of the t-test show that partially the independent variables in GCG, namely information disclosure, accountability, responsibility, independence, fairness, are stated to not affect the financing of fraud. This is because the number of R squares has a small effect. After all, it is below $50 \%$ so that the impact on the insignificance of the variables in GCG on fraud financing. Therefore, it results from the t-test in which none of the $\mathrm{X}$ variables affect variable Y. From the information above, it can be concluded that the GCG variable simultaneously has a significant effect on financing fraud, but if tested partially, the GCG variable has no effect on financing fraud.
\end{abstract}

\section{Introduction}

The development of developing countries in the 21 st century in the era of globalization was faced with the growth of the world population, which continued to rise and move dynamically. Therefore, a giant battle of the world economy was witnessed called the tripolar economics game between Japan, the United States, and Western Europe (Suhendra and Murdiyah 2006). Likewise, Islamic banking is also growing in parts of the continent, especially in Indonesia. Along with this, a reliable bank management system is also needed, one of which is the implementation of GCG. The purpose of GCG is to avoid various kinds of loss risk, if not considered, will damage the perception of sharia in the future and will enter Islamic banks to the brink of collapse (Mingka 2011).

Research of corporate governance conducted by IRTI (Islamic Research and Training Institute) in Islamic banking in various countries showed that the implementation of GCG has not been appropriately implemented. Whereas the implementation of GCG in Islamic financial institutions in the Muslim world can increase public trust in Islamic banks, Failure to apply sharia principles will make customers change to other banks by $85 \%$ (Chapra and Habib 2002). Happened to the Dubai Islamic Bank, which lost around US\$300 billion due to improper financial statements, and to the Islamic Bank of South Africa, which went bankrupt in 1997 with debts of between AED 50 to AED 70 million due to poor management, accounting, and management systems (Rini 2014). The existence of these cases proved that there is no guarantee that Islamic institutions, especially 
sharia-based banks, were free from fraud. It must be understood that religious symbols did not guarantee an institution clean from corrupt behavior because all humans have reason and lust, unlike angels. So, before the occurrence of cases that can damage the Islamic financial institutions, it is necessary to remind relevant parties early to commit to avoid any irregularities such as fraudulent financing that has recently occurred in Islamic banks.

The case of fraud is since GCG regulated governance that is carried out by considering all factors that affect institutional processes, including factors related to the function of the regulator. The corporate governance system should be shown to optimize financial results, emphasizing the shareholders' welfare. Thus, if all the actors and the relationship between the components of corporate governance proceed well, it is referred to as good corporate governance (Kasmir 2012). Emphasized in the research (Chapra and Habib 2002) in (El Junusi 2012), a total of 288 customers (62\%) of the 463 customers involved in the survey (from 14 Islamic banks in Bahrain, Bangladesh, and Sudan) stated that they would change their funds to another Islamic bank if it is suspected that there has been a "sharia violation (fraud)" in the operation of a sharia bank. This finding showed that compliance with sharia principles is significant in influencing customer behavior in choosing Islamic banks.

The principles of the GCG implementation include fairness, transparency, accountability, responsibility, ethics, and work culture. In Islamic teachings, these points become the essential principles in the activities and life of a Muslim. However, more than that, Islam is very intense in teaching the application of the principles of 'is (justice), tawazun (balance), mas'uliyah (accountability), akhlaq (morality), shidiq (honesty), amanah (fulfillment of trust), fathanah (intelligence), tabliqh (transparency, openness), hurriyah (independence and responsible freedom), ihsan (professional, wasathah (fairness), ghirah (sharia militancy), idara (management), khilafah (leadership), aqidah (faith), ijabiyah (thinking). positive), raqabah (supervision), qira'ah and islah (organizations that continue to run and continuously make improvements). This description can be ascertained that Islam far preceded the birth of GCG, which became a reference for good corporate governance in the world (Nur 2010).

Based on several research results and reports from the World Bank, the banking crisis in Indonesia and the collapse of the world's large companies were caused by poor implementation of GCG practices (Dwiridotjahjono 2009). Recent rapid developments in the growth of Islamic banking required the immediate implementation of GCG practices in banking management. The goal is to provide maximum protection to all interested parties (stakeholders), especially customers or depositors. Poor corporate governance can lead to fraud, as has happened in several banks in Indonesia. The application of GCG principles is necessary for all institutions, including financial institutions such as Islamic banks. The link lies with the responsibility to the community for the bank's operational activities, which are expected to comply with applicable regulations strictly. This regulation is contained in Law No. 40 of 2007 concerning Limited Liability Companies, Law No. 10 of 1998 concerning Banking, and Law No. 21 of 2007 concerning Sharia Banking.

In line with the demands for the implementation of GCG in the banking sector, in 2006, Bank Indonesia initiated a regulation that specifically regulated the provisions on the implementation of GCG in Commercial Banks; Bank Indonesia Regulation Number 8/4/PBI/2006 dated January 30, 2006, concerning Implementation of GCG for Banks General which was again refined through PBI No. 8/14/PBI/2006 dated October 5, 2006, concerning Amendments to PBI No. 8/4/PBI/2006, then revised PBI Number 11/33/PBI/2009 dated December 7, 2009, and Circular Letter of Bank Indonesia Number 12/13/DPS dated April 30, 2010, concerning Implementation of GCG for Sharia Commercial Banks and Sharia Business Units. The emergence of this law is the urgency of the importance and the urgency of the implementation of GCG in 
Islamic banking as a trust institution. This reason is the basis of this research due to the emergence of corporate governance weaknesses in the Islamic banking industry, which increasingly attract experts in Islamic economics and finance (Asrori 2014). Therefore, implementing good corporate governance, especially having added value based on Islamic principles, gave an indication and impression to the public that Islamic institutions, especially banks, are protected from fraudulent practices, even though fraud could occur anywhere.

Because of the dangers of fraud in banking financing, it is very urgent to research to mitigate the effects of fraud. So it is essential to know the effectiveness and influence on the implementation of GCG. The output of this research is enormous, especially for companies mitigating financing risk. They can provide input for banks to improve the quality of human resources in preventing fraud. For academics, this research aims to strengthen and test theories to improve qualified banking human resources quality to prevent fictitious financing. In addition, the purpose of this study is to find out the actual condition of human resources in Islamic banking on the implementation of GCG so that they can further improve their quality as prospective bankers. For the general public, it is intended to find out the causes of fraudulent financing so that the general public does not have a wrong perception of Islamic banking. In addition, to eliminate the paradigm of the wrong thinking of Islamic banking to be answered.

The growing development of Islamic banks has implications for the more significant challenges for Islamic banks. One of the biggest challenges is maintaining an image and good name in customers' eyes to maintain customer trust and loyalty to Islamic banks (Najib and Rini 2019). As we know, Islamic banks are banks that carry out their business activities based on sharia principles sourced from the Qur'an, Hadith, and Ijma' of the scholars, which are applied both within and outside the company (Maradita 2014). Then the question arises whether the existence of sharia elements guaranteed an institution free from fraud? In fact, no, as evidenced by the existence of cases of fraud that occurred in sharia institutions. The case from Bank Syariah Mandiri involved internal bank parties, namely the distribution of fictitious loans at the Bogor branch of BSM amounting to 102 billion rupiahs to 197 fictitious customers. As a result of the credit distribution, BSM can suffer a loss of 59 billion rupiahs. In this case, the police named four suspects, three of whom were BSM employees (Prabowo 2012).

Every transaction process activity must always refer to the concept of benefit and uphold the principles of justice. In addition, the principle emphasizes that economic actors must be based on ethical and legal norms in economic activities. The realization of the sharia concept, basically the sharia economic/banking system has three essential characteristics, namely the principle of justice, avoiding prohibited, and paying attention to aspects of benefit (Zainudin 2008). In the implementation of its operating system, Islamic banks must reflect Islamic economic principles. Forms of values can generally be divided into two perspectives, namely micro and macro. Sharia values in a micro perspective emphasize aspects of competence/professionalism and trustworthiness. Meanwhile, in the macro perspective, sharia values emphasize the distribution aspect, prohibition of usury, and economic activities that do not provide tangible benefits to the economic system. Therefore, it can be seen that the potential benefits of the existence of a sharia financial/banking system are shown not only to members of the Islamic community but to all humankind (Rahmat Lil Alamin-Rahmat for the entire universe).

The Cadbury Committee defined good corporate governance as a system that directs and controls the company to balance the power of authority required to ensure its continued existence and accountability to stakeholders. This is related to the regulatory authority of owners, directors, managers, shareholders, etc. (Cadbury 1997). 
The Organization for Economic Corporation and Development (OECD) defined corporate governance as a set of relationships between company management, boards, shareholders, and other parties interested in the company. Corporate governance also required the existence of a device structure to achieve goals and control over performance. Good corporate governance can provide incentives for the board and management to achieve goals in the company's interest, and shareholders must facilitate adequate supervision to encourage companies to use resources more efficiently (Tunggal, Iman Sjahputra Tunggal 2002).

As an intermediary and trust institution, in carrying out its business activities, banks must adhere to the principle of transparency, have performance measures from all levels of the bank based on measures that are consistent with corporate values, business objectives, and bank strategies as a reflection of bank accountability (accountability), adhering to prudential banking practices in ensuring the implementation of applicable regulations as a form of bank responsibility (responsibility), objective and free from pressure from any party in decision making (independence), and always paying attention to stakeholders based on the principles of equality and fairness.

In practice, GCG can increase the company's value by improving financial performance and reducing risk in decisions. Generally, corporate governance can increase investor confidence. On the other hand, poor corporate governance can reduce the level of investor confidence. Corporate governance is concerned with fundamental issues concerning corporate management, supervision, and the methods that governance affects the interests of various stakeholders, especially for Islamic banking whose operations are based on Islamic principles as a public trust institution that puts their funds in Islamic banking to maintain public trust and increase values in Islamic banking (Sjahdemi 2004).

The Sharia Banking Law has established GCG as an obligation for all Sharia Banks and Sharia Business Units (Abdullah 2010). It described GCG as good governance, including transparency, accountability, responsibility, professionalism, and fairness in carrying out business activities. The law also required the bank concerned to develop internal procedures regarding the implementation of these principles. In addition to determining the principles of governance, Law Number 21 of 2008 concerning Islamic Banking also specifically regulated the obligation to apply prudential principles and risk management as an essential part of GCG. To ensure the implementation of decision-making in bank management following the prudential banking practices (Prudential Banking Practices). Sharia banking must have and implement an internal supervision system and comply with Bank Indonesia regulations regarding the maximum limit for disbursing funds based on sharia principles, providing guarantees, placement of sharia-based securities investments, or other similar matters. All of this must be done so that Islamic Banking always takes ways that do not have negative effect the company and the interests of customers who entrust their funds to them. In addition, so that there is no rush due to the loss of trust from the community.

Fraud is a case that is always possible in every financial transaction carried out by banking institutions. Naturally, if a banking institution, fraud can be classified as a very "terrible" economic crime, especially for the integrity and credibility of the banking institution that experienced the fraud. This is because the bank as an institution relies heavily on the trust of its service users. Integrity and credibility are crucial things to maintain to continue carrying out their intermediation function (Rustendi 2009). In criminology, fraud is a fraud that is intentionally carried out by a person or group of people so that it causes losses without being realized by the injured party and provides benefits for the perpetrators of fraud. 
The banking world is one of the areas of business that is vulnerable to crime in the form of fraud. So it can be said that fraud is not a crime that has just been recognized in the banking world because the practice of fraud itself is as old as the banking world (Demir-Araz 2002). Scientifically, fraud committed by internal parties has emerged a theory related to the causes of fraud which is justified by fraud experts both nationally and internationally. This theory is known as the "Fraud Triangle." The fraud triangle includes three elements such as pressure/motivation, opportunity, and rationalization. Based on this fraud triangle, experts believe that if one of the three elements is not present, then fraud will not occur.

Because of the dynamic nature of human needs, this condition required an organization/company to provide human resources to consistently design and produce quality products. The HR paradigm as a complementary tool to the organization is no longer appropriate and must become a new paradigm. The new paradigm in question is to position HR as an asset managed optimally to realize organizational goals. Employees as company assets must be maintained and developed because employees have emotions, desires, demands, needs, and limitations. The need for reliable human resources as the foundation for developing Islamic economics in Islamic financial institutions and banking is a challenge and an opportunity (Nawawi 2003).

The operation of Islamic banks is inseparable from the demands of implementing good corporate governance. It is also based on sharia principles known as Islamic corporate governance. This demand for governance was caused by the crisis that occurred in the banking sector, which was generally dominated by conventional banking in 1997, which continued until 2000. The banking crisis that influenced Indonesia did not result from the decline in the rupiah exchange rate but because of the ineffectiveness of GCG practices in Indonesia. Banking circles. The occurrence of violations of the maximum lending limit, standard risk management practices, lack of transparency of financial information to customers, and the dominance of shareholders in regulating banking operations have caused the fragility of the national banking industry (Maradita 2014).

Every research ideally proves a hypothesis. It will be more weighty if the hypothesis provides impact and impact factors for developing scientific disciplines following the problem. This article will answer the hypothesis related to the GCG variable on the proof of fraud financing in Islamic banking. In more detail, it will examine the independent variables in the form of information disclosure, accountability, responsibility, independence, fairness affecting the dependent variable in fraud financing. The final result will prove whether or not there is a substantial or weak role of GCG in the influence of fraud financing in Islamic banking.

\section{Research Method}

This research is mixed-method research that is a combination of quantitative and qualitative research. Researchers used primary and secondary data. The primary data are in interviews and questionnaires taken from several unit leaders of the bank concerned. Meanwhile, secondary data was obtained from relevant literature and documentation from BNI Syariah Bank using content analysis. The author issued a sample of 50 employees. Due to the total population at BNI Syariah Fatmawati Branch and BNI Syariah Sub-Branch UIN as many as 50 populations, the researchers used the following Slovin formula:

$$
\mathbf{n}=\mathbf{N} / \mathbf{1}+\mathbf{N}(\mathbf{d})^{2}
$$


The results of the calculation of the Slovin formula are obtained at least 33 samples. Then the author gave a questionnaire to 50 samples, but not all of them were filled in by respondents because respondents returned only 39. Case Study This research was conducted at Bank BNI Syariah Fatmawati Branch and BNI Syariah Sub-Branch UIN Syarif Hidayatullah Jakarta. By using the method of correlation analysis and multiple linear regression with the following model:

$$
\mathbf{Y}=\alpha+\beta_{1} \mathbf{X}_{1}+\beta_{2} \mathbf{X}_{2}+\beta_{3} \mathbf{X}_{3+} \beta_{4} \mathbf{X}_{4+} \beta_{5} \mathbf{X}_{5}
$$

Furthermore, the proof with the results of the hypothesis is namely testing the validity and reliability of the data plus simultaneous testing and partial testing using 50 samples from the employee population of BNI Syariah Fatmawati Branch and BNI Syariah Sub-Branch of UIN Syarif Hidayatullah. The data is processed using SPSS. At the same time, the independent variables consist of information disclosure, accountability, responsibility, independence, and fairness. This research is expected to produce a descriptive picture of which independent variables have a significant or insignificant effect on fraud financing in Islamic banking.

\section{Results and Discussions}

The identity of the respondents in this study was Bank BNI Syariah Fatmawati Branch and BNI Syariah Sub-Branch UIN. The description of the sample based on gender, age, last education is presented as follows, 18 male or $46.15 \%$ and 21 women or $53.84 \%$, respondents based on age are obtained aged $20-25$ years amounting to $15 \%$ or $38.46 \%$, for respondents aged $25-30$ years totaling 18 people or $46.15 \%$ and for respondents aged $35-40$ years totaling six people or $15.38 \%$. The respondents based on their last education, all respondents graduated from S1 or $100 \%$.

The study results that GCG is a part of the company system of Bank BNI Syariah. It has been regulated in the provisions of good corporate governance, and the sharia aspect is a guide at BNI Syariah. GCG is one way to prevent fraud. GCG has a significant effect on operations at BNI Syariah banks because GCG is part of a stringent and transparent banking system. All incoming and outgoing financial reports must have a basis and very clear underlines. In practice, the implementation of BNI Syariah's GCG is based on the applicable laws and regulations, especially those that regulate the implementation of GCG, namely the Sharia Banking Law number 21 of 2008 and Bank Indonesia Regulation number 11/33/PBI/2009 regarding the implementation of GCG for Sharia Commercial Banks and Units. Sharia Business, based on these provisions, refers to 5 (five) GCG principles, namely:1. The principle of fairness 2. The principle of transparency (transparency). 3. The principle of responsibility (responsibility) 4 . The principle of accountability (accountability) 5. The principle of professional (Professional).

In data analysis, initially, the researchers tested the instrument with validity and reliability tests. For the validity test, it was found that all independent and dependent variables were free from validity by Pearson's test with a significance below 5\% (0.05). As for the reliability test, Cronbach's alpha test was performed. The result is all variables $>0.6$, which states that the variable is reliable. 


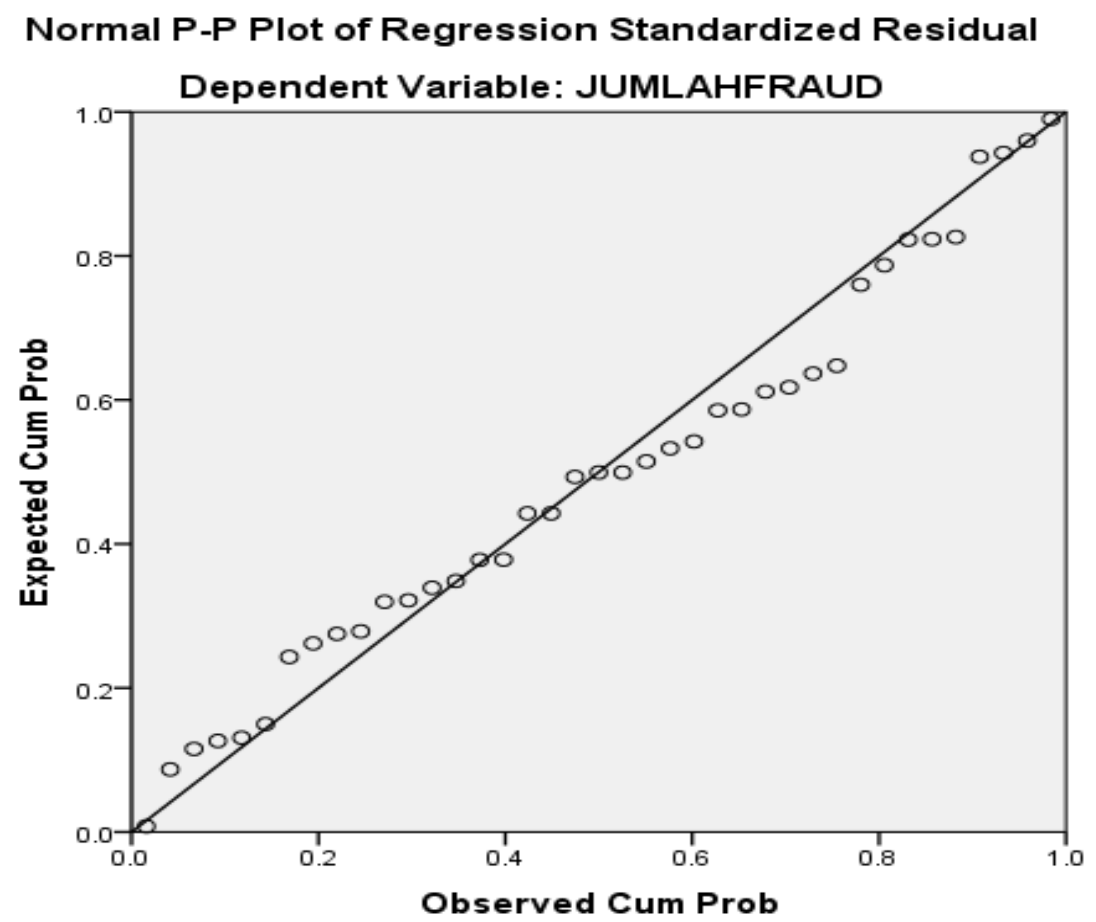

Figure 1. Linearity Test Results

From the table above, it can be seen that the plot has a straight shape with scattered plots following it. Based on the deviation of the points, which are relatively not far from the line, it can be concluded that this model is the normal test because the residuals have followed the normal distribution.

Table 1. Model R Square

\begin{tabular}{lllllc}
\hline Model & $\mathbf{R}$ & R Square & $\begin{array}{l}\text { Adjusted } \\
\text { Square }\end{array}$ & $\begin{array}{l}\text { RStd. Error of theDurbin-Watson } \\
\text { Estimate }\end{array}$ \\
\hline 1 & $.589^{\mathrm{a}}$ & .347 & .249 & 1.473 & 1.899 \\
\hline
\end{tabular}

From the results of the research regression model, the model as above is obtained. Judging from the results of testing the data on respondents at BNI Syariah Fatmawati Branch and BNI Syariah Sub-Branch of UIN Syarif Hidayatullah, it shows several conclusions, namely the resulting regression results are pretty small, namely $34.7 \%$, so that in this case it can be interpreted that the variable Information disclosure, accountability, responsibility, independence, and fairness can explain $34.7 \%$ so that it affects the financing of fraud at BNI Syariah Fatmawati Branch and BNI Syariah Sub-Branch of UIN Syarif Hidayatullah. The results are tested again for correctness seen from the t-test results showing that partially (separately) the independent variables in GCG, namely information disclosure, accountability, responsibility, independence, fairness, are declared unable to affect fraud financing. The $\mathrm{R}$ square $=34.7 \%$ has a negligible effect because it is below $50 \%$.

The results above are actually by previous research, not much different. As Aulia's research results, the implementation of GCG affects the same institution as BNI Syariah as the sampling of this research, namely Bank Mega Indonesia. The results of a small R Square turn out to be the same as Aulia's research, which stated that there is a need for management improvement in the implementation of GCG (Aulia 2012). In line with the results of Pranata's research, it concludes 
that investors who will invest their funds in go public companies that implement GCG should choose companies that have a high GCG score. In another sense, this GCG variable influences a person's decision to invest (Pranata 2007).

Table 2. About the F-Test in SPSS

\begin{tabular}{lllllll}
\hline Model & & Sum of Squares & Df & Mean Square & F & Sig. \\
\hline \multirow{2}{*}{1} & Regression & 38.126 & 5 & 7.625 & 3.514 & $.012^{\mathrm{b}}$ \\
& & & & & \\
& Residual & 71.618 & 33 & 2.170 & & \\
\hline
\end{tabular}

From the table above, it is known that the calculated $\mathrm{F}$ value $=3.514$ with $=0.012$ means $\mathrm{F}$ arithmetic $>\mathrm{F}$ table because it is seen from the significance of $<5 \%$, so that from all regression models used, there is an influence between information disclosure, accountability, responsibility, independence and fairness of the financing of fraud together or simultaneously. From the conclusion, the model shows a significant effect. In a sense, although the R Square is relatively small, the test of the effect of the independent variable turns out to affect the dependent variable. Although partially it is not known directly which variable has the most influence or vice versa, which variable has the almost negligible effect. Thus, in the next partial test, which variables have the most significant or most negligible influence will be seen in detail.

Table 3. Hasil Uji t

\begin{tabular}{llllll}
\hline Model & \multicolumn{2}{l}{$\begin{array}{l}\text { Unstandardized } \\
\text { Coefficients }\end{array}$} & $\begin{array}{l}\text { Standardiz T } \\
\text { ed } \\
\text { coefficients }\end{array}$ & Sig. \\
& B & \multicolumn{3}{l}{ Std. Error Beta } \\
& .155 & 1.269 & & .122 & .904 \\
\hline (Constant) & .395 & .266 & .263 & 1.484 & .147 \\
$\quad$ Keterbukaan informasi & -.028 & .130 & -.039 & -.216 & .831 \\
$1 \quad$ Akuntabilitas & .168 & .126 & .228 & 1.335 & .191 \\
Pertanggung jawaban & .131 & .120 & .191 & 1.097 & .281 \\
$\quad$ Kemandirian & .080 & .125 & .110 & .638 & .528 \\
\hline
\end{tabular}

From the analysis of the data results, it can be seen that there is no effect from each independent variable to fraud. This is because the small $\mathrm{R}$ Square is equal to $34.7 \%$, resulting in the results of the t-test that none of the $\mathrm{X}$ variables affect the $\mathrm{Y}$ variable. Calculated $\mathrm{F}$ value $=$ 3.514 with $=0.012$ means $\mathrm{F}$ count $>\mathrm{F}$ table because it is seen from the significance of $<5 \%$ so that from all regression models used, there is an influence between information disclosure, accountability, responsibility, independence, and fairness to joint fraud financing -identical or simultaneous.

As previously above, the $\mathrm{R}$ Square calculation result is $34.7 \%$. These results are classified as not significant because they are below 50\%. This small result resulted in the independent variable having no significant effect when tested on the t-test. Because the validity and reliability tests have been carried out, the test results can be accepted. So that for next, the next researcher 
will add independent variables included from the GCG variable. Instrument questions should also be added and modified to avoid bias in the meaning of the respondents.

The implementation of GCG at BNI Syariah is running well and smoothly. This sentence is reflected in the results of the self-assessment of GCG implementation, which received a composite predicate of "excellent" means that the following aspects support the strength of BNI Syariah's GCG implementation; the implementation of the duties and responsibilities of the Board of Commissioners and the Board of Directors, the implementation of the duties and responsibilities of the Committees that support the duties and responsibilities of the Board of Commissioners, the implementation of the compliance function that runs by the applicable laws and regulations, the Internal Audit and the External Audit that carry out their functions independently and objective. These findings are in line with Busyeri's research, the results of which assess internal audit on developments in the bank, namely from just a unit that checks compliance, to a function that plays an active role as a partner for management in supporting the implementation of GCG (Busyaeri 2008). This compliance value is one of the indicators in the implementation of GCG. Compliance can be interpreted as an effort to comply with existing regulations, and GCG has an accountability variable. There is nothing contradictory between these two studies.

From the theory and previous research, it can be seen that the better the implementation of corporate governance, it is expected that the fewer the number of frauds that occur in Islamic banks. Whether or not the implementation of good governance in Islamic banks can be seen from the results of the self-assessment conducted by Islamic banks by the procedures described in BI Circular Letter No. 12/13/DPbS concerning the implementation of GCG for Sharia Commercial Banks and Sharia Business Units, wherein the BI Circular Letter the assessment of the implementation of corporate governance is seen from the composite value of the self-assessment results, in which the more minor the composite value, the better the level of implementation. Governance at the Islamic bank. So it can be concluded that the smaller the composite value of the Islamic bank self-assessment results, it is expected that the fraud that occurs will be lower or less.

In addition to the strength of BNI Syariah's GCG implementation, BNI Syariah's GCG implementation also has several things that need to be completed. Regarding these matters, BNI Syariah is committed to continuing to make improvements to realize GCG. The variables seen between the effects are information disclosure, accountability, responsibility, independence, fairness. Based on the model above, related variables such as information disclosure, accountability, responsibility, independence, fairness have a minimal effect, namely $34.7 \%$ on fraud financing at Bank BNI Syariah Fatmawati Branch and BNI Syariah Sub-Branch UIN Syarif Hidayatullah. In other words, there are still many factors that influence the occurrence of fraud financing. This means that it must be seen widely on the things that can affect the financing of fraud in Islamic banking. The factors that influence fraud financing are numerous, such as management in Islamic banking, customer character, economic conditions, customer's ability to pay installments, government bureaucracy, and the vital role of the audit committee and sharia supervisory board. In general, it can be said that good corporate governance is very influential because it is part of the management system in BNI Syariah Fatmawati Branch and BNI Syariah Sub-Branch of UIN Syarif Hidayatullah.

The results of an interview from one of the branch head representatives show that GCG has a significant influence on the prevention of fraud financing. GCG is part of the company's management. So, it is implemented with a high level of trust. In the context of the implementation of GCG, it can be seen that the managers of the BNI Syariah Bank Fatmawati Branch and BNI Syariah Sub-Branch of UIN Syarif Hidayatullah refer to the principles and values of sharia itself. The implementation of GCG at BNI Syariah also requires the commitment and involvement of all 
parties, both internal and external parties of Islamic banks. Islamic banks are encouraged to always comply with GCG principles to build the reputation of Islamic banks as Uswatun Hashanah and provide optimal contributions in improving people's welfare, reducing poverty and unemployment.

\section{Conclusions}

The results of this study indicate that the implementation of GCG can prevent fraud. On the other hand, if the company does not implement GCG, the possibility of fraud will be more significant because the company's management does not run in a professional, transparent, accountable, and accountable manner. Implementing GCG at BNI Syariah Fatmawati Branch and BNI Syariah Sub-Branch of UIN Syarif Hidayatullah has been effective because it has been running well judging from the role of internal and external audits, which have never indicated any fraud financing. In implementing the Bank Indonesia Regulation mandate, BNI bank established a Good Corporate Governance Policy Guideline to protect stakeholders and improve compliance with applicable laws and regulations and generally accepted values or ethics in the Islamic banking industry. These results indicate that the internal control applied to the agency can prevent fraud effectively and reduce the opportunity for individuals to commit fraud. In the test case above, the GCG principles, when tested alone, certainly do not affect fraud financing, but when tested as a whole, GCG certainly has a significant effect on fraud financing. This is due to the small value of $\mathrm{R}$ Square. Improving the quality of human resources must be a commitment for the management of Islamic banks. BI laws and regulations with the characteristics of Islamic banks are prerequisites for the creation of proper supervision and GCG for Islamic banking. For further research, the author suggests increasing the number of employees and employees in the special section of financing. In addition, it is recommended to use other methods such as DEA, CAMEL, and other measuring tools so that the results obtained are more optimal, precise, and measurable.

\section{References}

Abdullah, Mal An. (2010). Corporate governance Perbankan Syariah Di Indonesia. Ar Ruz Media. Asrori. 2014. "Implementasi Islamic Corporate governance Dan Implikasinya Terhadap Kinerja Bank Syariah" 6 (1): 90-102.

Aulia, Rica. (2012). "Penerapan Good Corporate Gevernance (GCG) Pada PT. Bank Syariah Mega Indonesia: Analisis Self Assessment Berdasarkan SEBI No. 9/12 DPNP Tanggal 30 Mei 2007." UIN Syarih Hidayatullah Jakarta.

Busyaeri, Ahmad. (2008). "Urgensi Audit Internal Dalam Mewujudkan Good Corporate governance Pada Bank Syariah (Studi Pada PT. Bank DKI Syariah Jakarta)." UIN Syarif Hidayatullah Jakarta.

Cadbury, Komite. (1997). The Business Roundtable, Statement On Corporate governance. Washington DC.

Chapra, Umar, and Ahmed Habib. 2002. Corporate governance in Islamic Financial Institutions. Jeddah: Islamic Research and Training Institute (IRTI).

Demir-Araz, Yeliz. (2002). "No Title." International Trade Law and Regulation 8 (4): 128-35.

Dwiridotjahjono, Jojok. (2009). "Penerapan Good Corporate governance: Manfaat Dan Tantangan Serta Kesempatan Bagi Perusahaan Publik Di Indonesia." Jurnal Administrasi Bisnis Unpar 5 (2): 101-12. https://doi.org/10.26593/jab.v5i2.2108. 
Junusi, Rahman El. (2012). "Implementasi Shariah Governance Serta Implikasinya Terhadap Reputasi Dan Kepercayaan Bank Syariah.” Al-Tahrir: Jurnal Pemikiran Islam 12 (1): 87. https://doi.org/10.21154/al-tahrir.v12i1.48.

Kasmir. (2012). Manajemen Perbankan Edisi Revisi. Jakarta: PT Raja Grafindo Persada.

Maradita, Aldira. (2014). "Karakteristik Good Corporate governance Pada Bank Syariah Dan Bank Konvensional.” Yuridika 29 (2): 191-204. https://doi.org/10.20473/ydk.v29i2.366.

Mingka, Agustianto. (2011). "GCG Bank Syariah Dan Peran DPS.” Www.Shariaeconomics.Com. 2011. https://shariaeconomics.com/tag/gcg-bank-syariah-dan-peran-dps.

Najib, Haifa, and Rini Rini. (2019). "Sharia Compliance, Islamic Corporate governance Dan Fraud Pada Bank Syariah.” Jurnal Akuntansi Dan Keuangan Islam 4 (2): 131-46. https://doi.org/10.35836/jakis.v4i2.23.

Nawawi, Hadari. (2003). Perencanaan Sumber Daya Manusia. Yogyakarta: Gadjah Mada University.

Nur, Rikza Ahmad. (2010). "Konsep Good Corporate governance (GCG) : (Studi Komparatif Antara Konsep GCG Bank Muamalat Indonesia Dan Bank Tabungan Negara).” UIN Jakarta.

Prabowo, Dani. (2012). "Kredit Fikti BSM Terendus Sejak 2012, 3 Pegawai Sudah Dipecat." Megapolitan Kompas, 2012. http://megapolitan.kompas.com/.

Pranata, Yudha. (2007). "Pengaruh Penerapan Good Corporate governance Terhadap Kinerja Keuangan Perusahaan.” Universitas Islam Indonesia.

Rini, Rini. (2014). "The Effect of Audit Committee Role and Sharia Supervisory Board Role on Financial Reporting Quality at Islamic Banks in Indonesia.” Journal of Economics, Business, \& Accountancy Ventura 17 (1): 145. https://doi.org/10.14414/jebav.v17i1.273.

Rustendi, Tedi. (2009). "Analisis Terhadap Faktor Pemicu Terjadinya Fraud (Suatu Kajian Teoritis Bagi Kepentingan Audit Internal).” Jurnal Akuntansi 4 (2): 705-14.

Sjahdemi, Sutan Remy. (2004). Perbankan Syariah Produk-Produk Dan Aspek-Aspek Hukumnya. Jakarta: Prenada Media Group.

Suhendra, and Hayati Murdiyah. (2006). Manajemen Sumber Daya Manusia. Jakarta: UIN Jakarta Press.

Tunggal, Iman Sjahputra Tunggal, Amin Widjaja. (2002). Membangun Good Corporate governance (GCG). Jakarta: Harvarindo.

Zainudin. (2008). Hukum Perbankan Syariah. Jakarta: Sinar Grafika. 